Original article

\title{
The Effectiveness of Vitamin D, Succimer and Safety \\ Precaution Measures in Regulation of Elevated Blood Lead in Fuel Station Workers.
}

\author{
Makloph $\mathrm{MG}^{1}$, Mohamed Masoud ${ }^{2}$ \\ ${ }^{1}$ Department of Forensic medicine and Clinical toxicology, Faculty of medicine, \\ Fayoum University. ${ }^{2}$ Department of public health, Faculty of medicine, Fayoum \\ University.
}

\section{ABSTRACT}

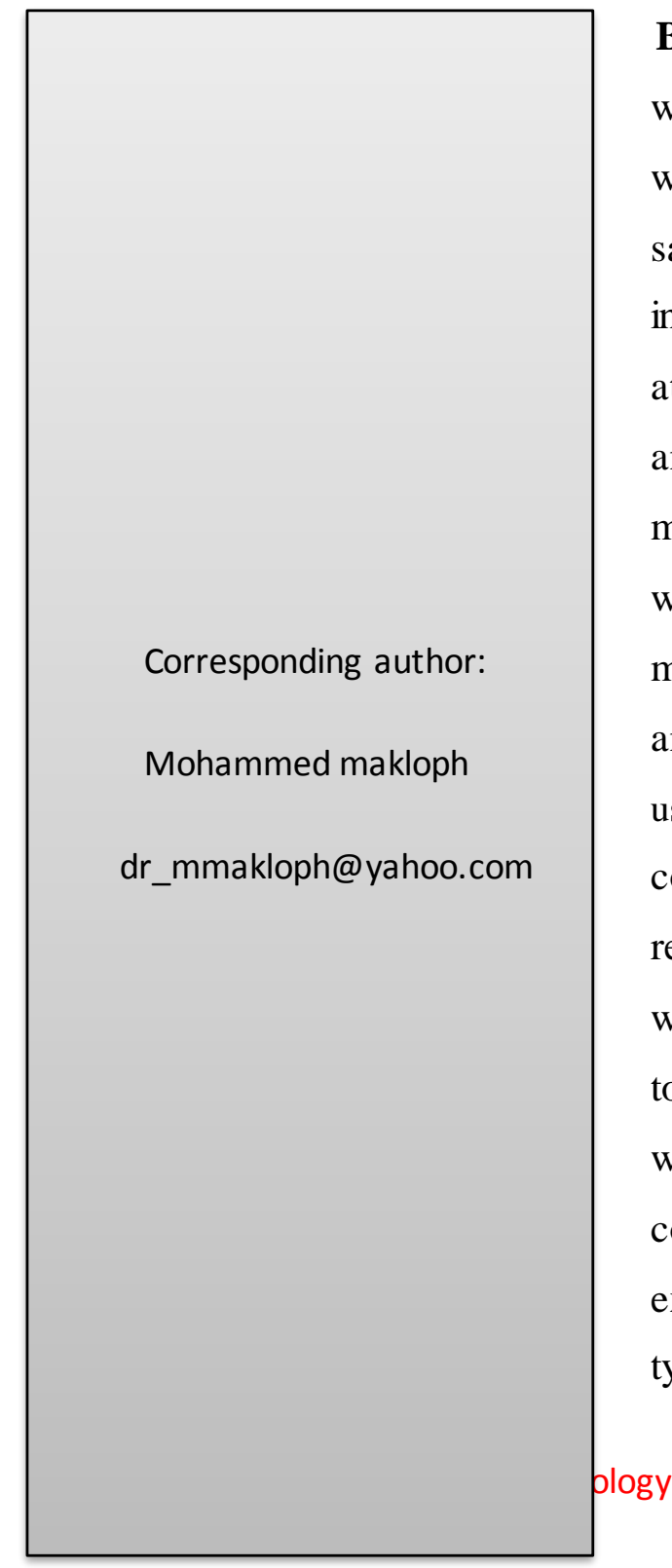

Background: Continuous exposure to air polluted with the vapor of lead (in leaded gasoline) by the workers in petroleum stations without following safety measures, results into elevated level of inorganic lead in blood of those workers and put them at increased risk of toxicity through exposure to lead and its products. The aim of the present study is to measure concentration of lead in blood of fuel station workers. Subject and methods: Lead in blood was measured through lead care of blood testing system and lead care of blood testing kits, and confirmed by using Atomic Absorption Spectrophotometry(AAS) for confirmation and checking quality of measuring and repeat measuring of lead concentration in blood of workers with blood lead conc.> $50 \mu \mathrm{g} / \mathrm{dl}$. This study took two approaches: a case-control approach in which 76 Petroleum station workers and age-matched control participants were included, and an experimental approach in which the effect of various types of lead decreasing agents was investigated after 
giving medications and taking certain precautions. RESULTS : blood lead conc in petroleum station workers was higher than normal ,so by using interventions, Such as giving vit, D, lead chelating agents(Succimer) and certain safety precautions (mask, gloves, boot, cap, special clothes and regular skin cleaning and well balanced calcium enriched food ) show effectiveness in control and regulation of blood lead level. Conclusion: From the current study it was concluded that following safety measures, receiving succimer, and vit, D supplementation helped in decreasing elevated blood level in fuel station workers.

Key words: Lead, Petrol, Vit, D, Abstinence, Succimer, Vapor.

\section{I-INTRODUCTION:}

Lead is the most available metal in the earth crust and Lead poisoning has remained a global public health issue, particularly in developing countries. Toxicity of lead from exposure has been recognized years ago with the oldest published reports dated since prehistoric times (Shilu, 2000).

Lead poisoning is caused by ingesting contaminated water from lead-filled pipes in homes, or inhalation of airborne lead particles by workers (at lead mines and smelters), gasoline station workers are now commonly exposed to lead in their fuel stations as well. (Agency for Toxic Substances and Disease Registry, 2007).
The developed countries have formulated regulatory bans on leaded fuel, resulting in lower blood lead levels among their citizens (Muntner et al., 2005).

Residents of developing countries continue to have high blood lead levels due to a lack of regulatory laws prohibiting the use of leaded fuel, as well as a lack of education and awareness about the dangers and hazards of lead poisoning (World Health Organization, 2015).

The WHO now considers a higher level of blood lead to be $40 \mu \mathrm{l}$ /dl and necessitate treatment. Subclinical and clinical effects of plumbism may occur at levels lower

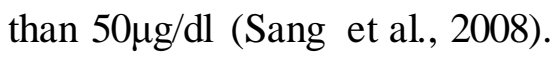


Lead toxicity has a wide ranє of effects on living tissues due 1 various mechanisms of action, such c the fact that it is a divalent cation that competes with calcium for receptors and affects signaling (Prasenjit et al, 2017).

Treatment of lead poisoning could be accomplished through the use of oral chelating agent, such as Succimer (2,3 dimercaptosuccinic acid), which results in a decrease in lead levels and, as a result, a decrease in lead poisoning (Abbasi et al., 2003).

The present study aimed at detecting the effect of following safety measures (mask, gloves, boots, cap, special clothes and calcium enriched food), receiving succimer and vit, D supplementation in control and regulation of blood lead conc. among fuel station workers.

\section{II-Subjects and methods}

\subsection{Study design}

This study took two approaches: a case-control approach in which 76 Petroleum station workers and agematched control participants were included, and an experimental approach in which the effect of various types of lead decreasing agents was Zagazig J. Forensic Med\& Toxicology investigated. The current study lasted six months, from April 2019 to September 2019.

\subsection{Study sample}

The workers were selected at random from four petrol filling stations in Fayoum city. The control participants were chosen at nonrandom from nearby areas on the assumption of a low risk of lead vapor exposure.

Workers of fuel station with more than 5 years of work who are between the ages of 25 and 40 are eligible for inclusion in the study after signing written informed consent. We exclude those who refuse to participate, beyond the age limit and live beside factories or in polluted area and chronic ill patients or handicapped.

Regarding the control group they were age matched with the same socioeconomic level of the exposed subjects, with low risk of exposure to polluted environment with lead away from factories and in rural agricultural area, not diseased or treated of chronic illness. They were selected nonrandomly by quta sampling from their residence.

\subsection{Data collection}


Every participant was given a questionnaire in order to determine the length of time they had been exposed to lead vapors, and Demographic Data and smoking habits of each participant in the study.

A blood sample(with its all precautions regarding sampling, transfer and refrigeration) was collected from each individual who agreed to participate in the study, $50 \mu 1$ of whole blood collected in heparinized capillary tube by pin pricking tip of finger after cleaning of the skin as a screening for all subjects then $5 \mathrm{ml}$ venous blood withdrawn for confirmation, as the apparatus has the capacity of detection until 50-100 $\mu 1 / \mathrm{dl}$.

The collected sample was taken to the lab of Fayoum University Hospital to be analyzed for blood lead levels using the lead care of blood testing system \& lead care of blood testing kits by the same laboratory technician each time, the used kits are specific for measuring lead in fresh whole blood by quantitative assessment. Atomic absorption spectrophotometry (AAS) was used as an apparatus for measuring lead level in blood taking into consideration internal quality control and external quality assessment.

Subjects with high blood lead level(greater than $50 \mu \mathrm{g} / \mathrm{dl}$ ) were classified into 4 groups ,each formed of Eight subjects:

1-Group A, was given Active form of vitamin D (Calciferol) 10,000 international units daily $(250 \mathrm{mcg} / \mathrm{ml})$, each $1 \mathrm{mcg}$ equaling 40 international units, was given orally for one month to those with high blood lead levels, then blood lead levels were measured again using the same precaution(Harjit et al, 2017).

2-Group B, Subjected to one-week period of not working and follow safety measures(cap, glove, mask, boots, special clothes and regular skin cleaning) for a month then measuring blood lead levels.

3-Group C, given lead decreasing agent oral capsule (Succimer) 10mg/kg 3times per day for 5 days then $10 \mathrm{mg} / \mathrm{kg}$ twice per oral capsule for 14 days, then measuring blood lead level again with taking into consideration the same precautions(Sally, 2009).

4-Group D, one-week period of no work, follow safety measures, given succimer and active form of vit, D for 
one month then remeasure of blood lead.

\section{.4 Statis tical analys is}

The collected data were organized, tabulated, and statistically analyzed using social science statistical package (SPSS Inc, version 22). The mean and standard deviation (SD) of quantitative data were computed. When appropriate, the independent-t test for comparing between exposed and nonexposed , dependent-t test(paired sample t-test) was used as a test of significance after intervention. Categorical data were presented as

\section{III- RESULTS}

This study included 76 petroleum station workers and age-matched control participants from nearby areas. In terms of age and smoking habits, by using chi square there was no statistically significant difference between station workers and control group ( $\mathrm{p}=0.941)$, as seen in Table 1 .

Lead concentration was significantly higher in Petroleum station workers frequencies and percentages; chisquare tests were performed for categorical nominal variables as age and smoking habit.

\section{Ethical consideration}

The Fayoum Faculty of Medicine Research Ethical Committee approved this study according to the declaration of Hilsinki. The study was carried out after explaining the objectives of the study. All participants in the study provided verbal and written consent, and each individual had the right to refuse or accept participation in the study.

than control $(56.05 \pm 20.33$ vs. $14.32 \pm$ 6.59), with highly significant $\mathrm{P}$-value( $\mathrm{p}<0.0001$ ), as seen in Table 2.

Lead concentration(in group A subjects) decreased after vitamin D administration $(56.05 \pm 20.33$ to 47.57 \pm 22.03 ), but it was not a statistically significant $\mathrm{P}-$ Value $\quad(\mathrm{p}=0.472)$, by using (paired sample t-test as a test of significance).as seen in Table 3. 
Table 1: Age distribution of study participants (exposed workers and control group) by the independent-t test.

\begin{tabular}{|l|l|l|l|l|l|}
\hline \multirow{2}{*}{ Age groups } & \multicolumn{2}{|l|}{$\begin{array}{l}\text { Petroleum station workers } \\
(\mathrm{N}=76)\end{array}$} & $\begin{array}{l}\text { Control } \\
(\mathrm{N}=76)\end{array}$ & \multirow{2}{*}{ P-value } \\
\cline { 2 - 5 } & $\mathrm{N}$ & $\%$ & $\mathrm{~N}$ & $\%$ & \\
\hline $25-29$ & 26 & $34.2 \%$ & 24 & $31.6 \%$ & \multirow{2}{*}{0.941} \\
\hline $30-34$ & 20 & $26.3 \%$ & 21 & $27.6 \%$ & \\
\cline { 1 - 5 } $35-39$ & 30 & $39.5 \%$ & 31 & $40.8 \%$ & \\
\cline { 1 - 4 } Smoking & 68 & $89.5 \%$ & 33 & $43.4 \%$ & \multirow{2}{*}{0.078} \\
\cline { 1 - 5 } Total & 76 & $100 \%$ & 76 & $100 \%$ & \\
\hline
\end{tabular}

$\mathrm{N}$ : number of cases

Table 2: Lead concentration in fuel station workers in comparison to control groups by using independent $\mathrm{t}$-test with 2 tailed significance.

\begin{tabular}{|l|l|l|l|}
\hline & $\begin{array}{l}\text { Petroleum station } \\
\text { workers }(\mathrm{N}=76)\end{array}$ & $\begin{array}{l}\text { Control } \\
(\mathrm{N}=76)\end{array}$ & P-value \\
\cline { 2 - 3 } & Mean $\pm \mathrm{SD}$ & $<0.0001^{* *}$ \\
\hline $\begin{array}{l}\text { Lead level in } \\
\text { blood }\end{array}$ & $56.05 \pm 20.33$ & $14.32 \pm 6.59$ & \\
\hline
\end{tabular}

**Highly significant; $\mathrm{N}$ : number of cases

Table 3: Lead concentration according to measures taken in workers with lead concentration above $50 \mu \mathrm{g} / \mathrm{dl}$ after vitamin $\mathrm{d}$ administration.

\begin{tabular}{|c|l|}
\hline Group A & Mean \pm SD \\
\hline Lead at beginning & $56.05 \pm 20.33$ \\
\hline After vitamin D & $47.57 \pm 22.03$ \\
\hline P-value & 0.472 \\
\hline Number & 8 \\
\hline Period of treatment & One month \\
\hline
\end{tabular}


Table 4: Lead concentration after certain interventions to workers with lead concentration above $50 \mu \mathrm{g} / \mathrm{dl}$.

\begin{tabular}{|c|c|c|c|c|}
\hline & Group B & Group C & Group D & \multirow[t]{2}{*}{$\mathrm{P}$-value } \\
\hline & \multicolumn{3}{|l|}{ Mean \pm SD } & \\
\hline Lead level & $\begin{array}{ll}53.71 & \pm \\
7.40 & \end{array}$ & $44.97 \pm 11.05$ & $32.55 \pm 7.05$ & $<0.0001^{* *}$ \\
\hline Number & 8 & 8 & 8 & \\
\hline
\end{tabular}

$* *$ Highly significant

From the above table Workers' lead concentrations were found to be lower than before after Abstinence and follow safety measures(respiratory mask, cap, special clothes, gloves and boot) (Group B)(53.71 7.40) and after
(44.97 11.05) while after follow safety measures + lead decreasing agents and vit, $\mathrm{D}($ Group D) (32.55 7.05) with highly significant $\mathrm{P}$-value $(<0.0001)$ by using paired sample t-test, as seen in Table 4 and Figure 1.

Lead decreasing agents (Group C)

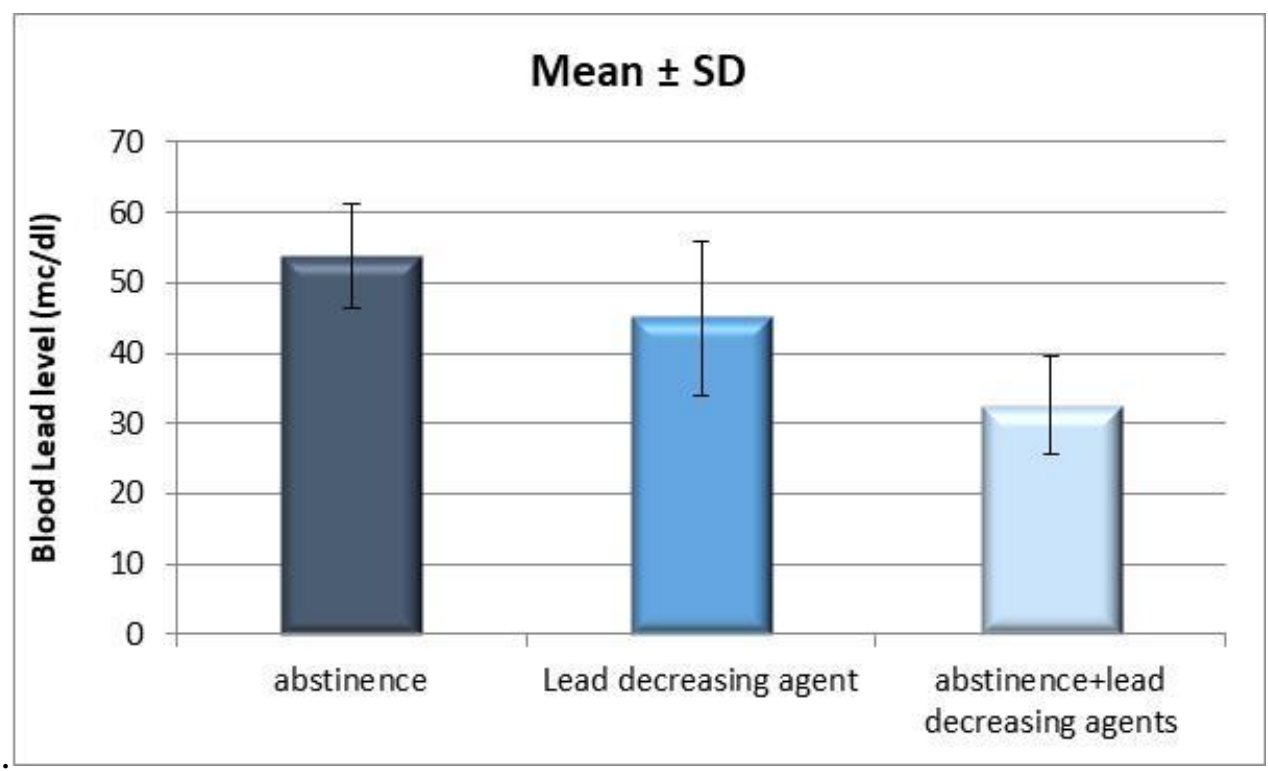

Figure 1: Lead concentration in workers(previously was above $50 \mu \mathrm{g} / \mathrm{dl}$ ) after abstinence and follow safety measures later, lead decreasing agents and both.

By using simple linear regression. duration and lead concentration in There was a statistically significant workers blood where spearman positive correlation between work correlation coefficient was strong and Zagazig J. Forensic Med\& Toxicology Vol (19) No.(2) July.2021 
positive $(\mathrm{r}=0.818)$, with

highly

length of the period in the fuel station

significant $\mathrm{P}$-value $(\mathrm{p}<0.0001)$ as the as seen in Figure 2.

lead level in blood increase by the

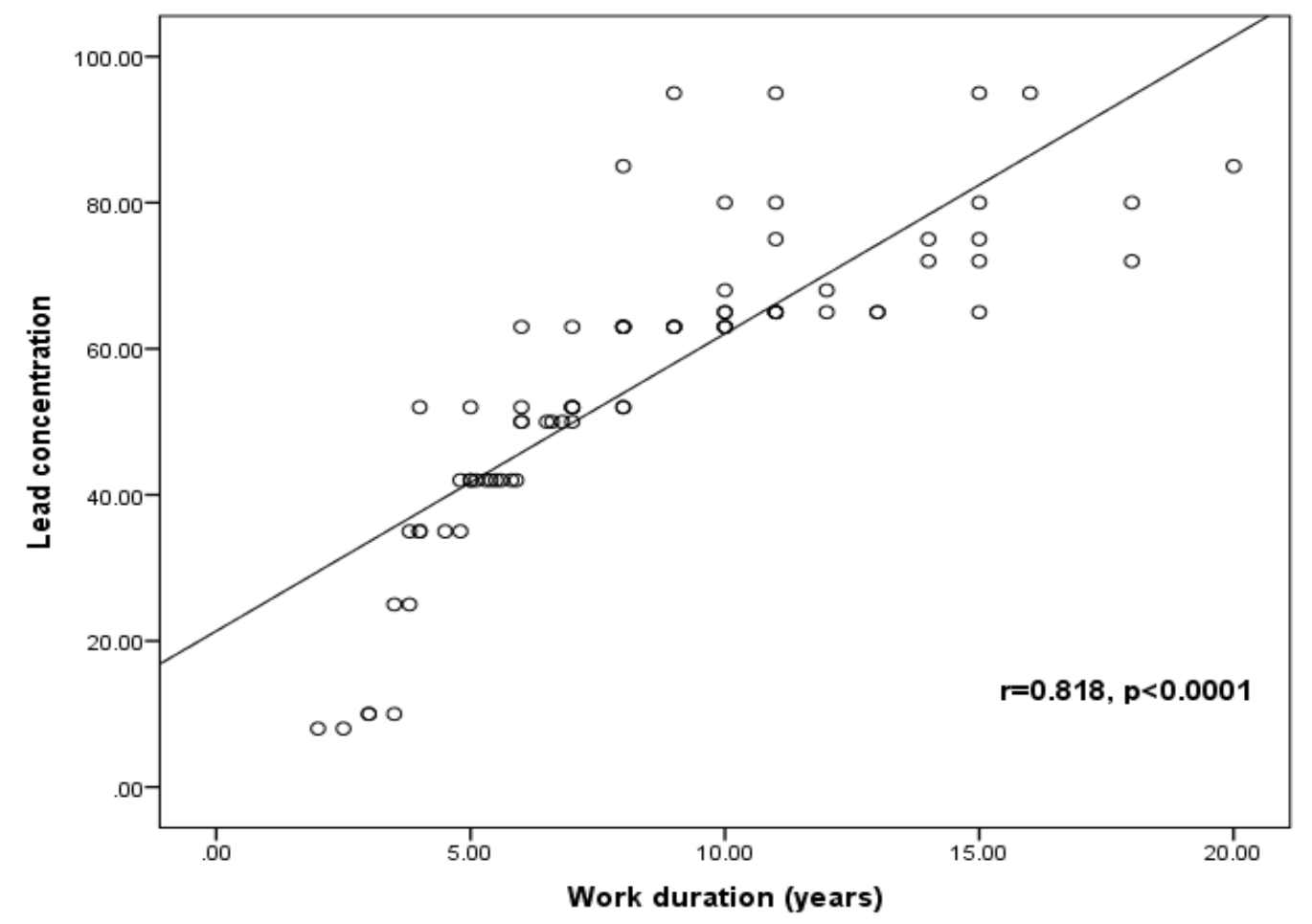

Figure 2 : Relation between lead conc. and work duration in a simple linear regression.

\section{IV-DISCUSSION}

Lead is one of the oldest known toxic substances that causes environmental hazards to patients worldwide by affecting various body organs such as the brain, bone, blood, and gastrointestinal tract. Various workers, such as those in gas stations, paint shops, and garages, are at a higher risk of exposure (Johnson et al., 2009).

We concluded in the current study that the mean blood lead level was higher in exposed individuals in fuel workers Zagazig J. Forensic Med\& Toxicology than in non-exposed workers, which was also found by( Al-Rudainy , 2010) in his study done in Albasra at the Republic of Iraqui, and (Nuwayhid , 2001) in his study in Beirut.

In the current study, exposed workers had higher blood lead levels than nonexposed adult workers. The elevated level of lead in the blood of exposed workers could be due to inhalation of airborne leaded vapor from a polluted environment at work due to a lack of Vol (19) No.(2) July.2021 
awareness of self-protection equipment and body clothes, or it could be due to absorption through the skin due to dehydration and neglection of skin cleaning the same was found by (AlRudainy , 2010) in his study in Albasrh

The current study showed that the longer the exposure time of workers to leaded vapor at the work station along years, the more higher the blood lead level, this was in accordance with those found by( Al-Rudainy , 2010) and (Mirsad et al., 2010).

Several factors affect lead absorption and hence lead level in blood such as, iron, calcium, zinc and vitamins such as Vit,D and $\mathrm{K}$. Vit, D act be dual mechanism as it affect calcium absorption and also lead affect metabolism of vit,D in body.(Anca , 2019)

The present study showed that regulation of exposure to lead vapor will result in decrease blood lead level in exposed workers, the same was found in the study done by (Jina et al, 2014) , (Trachtenbarg , 1996), And (Apotoli , 1998).

Succimer (DMSA) is a potent chelating agent more efficient than EDETA, which act on disulfide linkage chelating lead from blood and replenish bone store and taken orally leading to decrease in the blood lead level so it is commonly used in plumbism(Sally, 2009).

The present study showed that by using succimer as a chelating agent is highly significant for controlling blood lead level, the same was found in the study done by (Abbasi et al., 2003) and (Sally, 2009) where they found that by using oral chelating agent, we can control the blood lead level and reduce its concentration in the blood .

By follow up of subjects in the present study No symptoms of acute exacerbation of lead toxicity after usage of chelating agent(Succimer) for elevated blood lead level, the same was found in the study done by (Sally, 2009) except some cases shown constipation, controlled weakness and headache.

The current study found that the longer the duration of exposure to leaded vapor without protective clothing and equipment, the higher the blood lead level, which was consistent with the findings of (Al-Rudainy , 2010) and (Mason , 2005). 


\section{V- CONCLUSION}

Elevated blood lead levels among workers in petroleum stations resemble health hazards and potentially subject them to dangers, necessitating regulating laws and measures to control and regulate the elevated level of lead in blood, improving workers' quality of life and preventing later health hazards with all of their consequences and effects. The current study concluded that the effect of following safety measures(mask, gloves, boots, cap, special clothes), receiving succimer, and Vit D supplementation are effective in control and regulation of blood lead conc. among fuel station workers.

\section{Recommendation}

Follow safety measures for all workers in fuel station.

Calcium and vit $\mathrm{D}$ supplementation are advisable for workers.

Periodic investigation for lead and lead chelating agents is necessary for higher level even without complain.

\section{Conflict of interest}

the author declare that there is no conflict of interest.

\section{REFERNCES}

Abbasi J., Akhtarallen S. and Funnyejonathan A.: Gunshoot-induced Plumbism in an adult male. J. Nail Med. Assoc.2003;95:986-990.

Agency for Toxic Substances and Disease Registry: Toxicological Profile for Lead ,Atlanta,GA.2007;158-165.

Al-Rudainy LA.: Blood lead level among fuel station workers. J. Oman Med .2010;25(3):208-211.

Anca R. and Steven L: A Pharmacokinetic model of lead absorption and calcium competitive dynamics. Scientific Reports.2019;9:14225.

Apotoli P.: Trends in lead exposure in the work place and the environment.J. Ann. Ist. Super. Sanita.1998;34(1)121-129.

Harjit PB.,Jerzy K.,et al.: Vitamin D:Musculoskeletal health. Rev. Endocr. Metab. Disord.2017;18(3):363-371.

Jina K., Youngeun L. and Mihi Y.: Environmental exposure to lead $(\mathrm{Pb})$ and Variations in its susceptibility. J. Environ. Sci. 2014;32(2):159-185.

Johnson S., Saikia N. and Sadhu R.: Lead in paints. PML/PR.2009;34:1-37.

Mason H. and Williams N.: The decay of blood levels in workers suspended under the

Vol (19) No.(2) July.2021 
control of lead at work regulations.J. Occup.

Med.(London).2005;55(5):371-374.

Mirsad C., Mirjana M., Jasana K. and Amra C.: Occupational exposure of workers at gas station to inorganic lead .J. Med. Arh.2010;64(2):107-109.

Muntner P.,Menke A., Rabito FA., Desalyo KB., and Batuman V.: The National Health and Nutrition Examination Surveys.J. Arch. Intern. Med.2005;165:2155.

Nuwayhid I., Bu-Khuzam R. , Mcphaul K., Duh SH, Christenson RH. and Keogh JP.: Determinants of elevated blood lead among working men in greater Beirut. J. Med. Liban.2010;49(3):132-139.

Prasenjit M., Shailja S., Purvi P. and Praveen S.: Clinical and molecular aspects of lead toxicity :An update.Crit Rev Clin Lab Sci.2017;54(7-8):506-528.
Sally B. and Allister V.: Dimercaptosuccinic acid(Succimer;DMSA) in inorganic lead poisoning.Clin.

Toxicol.(Phila).2009;47(7):617-31.

Sang WT., Robert JR., Walter A., Jun PS., Aaron LS. and Geofferey MC.: Characteristics of US workers whose blood lead levels trigg er the medical removal protection provision and conformity with biological monitoring requirements. J. Am. Ind. Med.2008;51(9):691-700..

Shilu T., Yasmin EV. and Tippawan P.: Environmental lead exposure: a public health problem of global dimensions. J. Bulletin WHO..2000;78(9):1068-1077.

Trachtenbarg DE.: Getting the lead out : when is treatment necessary?. J. Postgrad. Med.1996;99(3):201-202,207-218.

World Health Organisation: Lead Exposure in African children. Contemporary Sources and Concerns. 2015;22 . 
فعالية فيتامين (د) ، و مخلبيات الرصاص(سكسيمر)وتدابير السلامة في تنظيم ارتفاع نسبة الرصاص في الام لاى العاملين في محطة الوقود.

ـ محمد مخلوف ا _محمد مسعود

اقسم الطب الثرعي و السموم الإكلينيكية_كليه الطب_جامعه الفيوم ق بسم الصحة العامة ـ كليه الطب جامعه الفيوم

الملخص العربي

مقدمه البحث: يؤدي التعرض المستمر للهو اء الملوث ببخار الرصاص (في البنزين المحتوي على الرصاص) من قبل العاملين في محطات البترول دون اتباع تدابير السلامة إلى ارتفاع مستوى الرصاص غير العضوي في دماء هؤلاء العمال ويزيد من خطر السمية من خلال التعرض للرصاص. ومنتجاتها.

الههف من البحث: دراسه تأثير إعطاء فيتامين دو عو امل مخلبية للرصاص (سوكيمر) واحتياطات أمان معينة (قناع وقفاز ات وحذاء وقبعة وملابس خاصةو تنظيف الجلد المنتظم) لمعرفة مدى فعاليتها في التحكم في مستوى

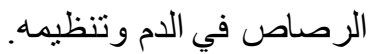

الطرق و الوسائل : . اتبعت هذه الدر اسة نهجين: نهج التحكم في الحالات الذي تم فيه تضمين VY عاملاً في محطة البترول ومشاركين في الضبط المطابق للعمر ، ونهج تجريبي تم فيه التحقق من نأثبر أنو اع مختلفة من فئن عو امل خفض الرصاص بعد إعطاء الأدوية و اتخاذ بعض الاحتياطات. من قبل العمال. وق شملت اللر اسة : ـ ـ ـالبيانات الديمغر افية الاجتماعية: وتتمل البيانات المتعلقة بالعمر التدخين و السكن. ـ ـ الفحوص المعملية: قياس نسبه الرصاص في دماء العاملين بمحطات الوقود. ז ـاعطاء فيتامين د ومخلبيات الرصاص ووسائل الوقاية لمجمو عات بحثيه وإعادة قياس نسبه الرصاص. تم تدوين البيانات الثخصية وكذلك نتائج الفحوص المعملية العلاج ـ وتم عمل تحليل إحصائي للمعطيات. النتائج: من الدر اسة الحالية استنتج أن اتباع تدابير السلامة ، تناول مكملات مخلبيات الرصاص succimer ، و فيتامين د ساعد في خفض مستوى الدم المرتفع في عمال محطة الوقود د. لئه

$$
\text { التوصيات: توصي الدر اسه بالاتي: }
$$

ا -تباع إجر اءات السلامة لجميع العاملين في محطة الوقود. r-بيُنصح العمال بمكملات غذائيه مثل تناول الكالسيوم وفيتامين د.

ب ـالفحص الدوري للرصاص و اعطاء ادويه لتقليله في حال تعدي النسبه المسموح بها حتى بدون شكوى 